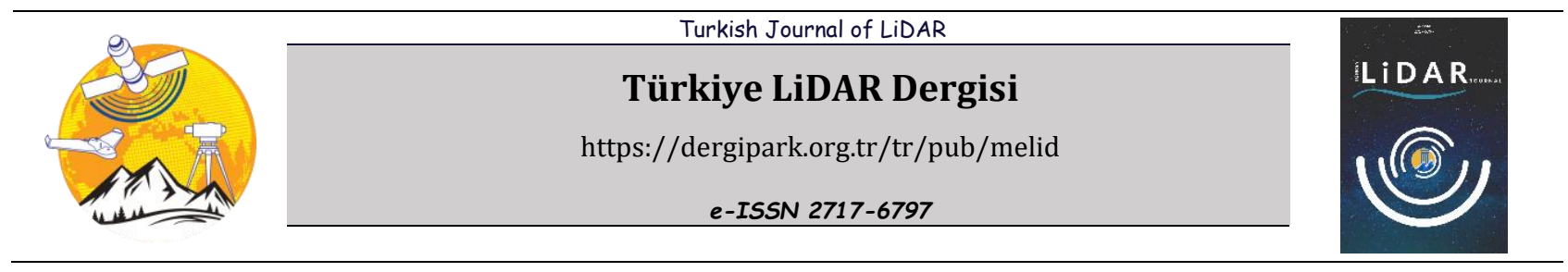

\title{
Documentation of Cultural Heritage with Backpack LiDAR Usage on Photogrammetric Purpose
}

\author{
Kasım Erdal1 ${ }^{\circledR}$, Hasan Bilgehan Makineci*1 ${ }^{\circledR}$ \\ ${ }^{1}$ Konya Technical University, Faculty of Engineering, Department of Geomatics Engineering, Konya, Turkey
}

\author{
Keywords \\ Backpack Lidar \\ Cultural Heritage \\ Documentation \\ GNSS/IMU Integrated \\ systems \\ 3D Model
}

\begin{abstract}
Architectural documenting is an essential requirement to identify the evidence of historical artefacts, be instrumental in their transmission to future generations, and document the destructions they have suffered. With photogrammetric methods in recent years, a new perspective has been given to survey investigations. The data obtained by 3D modelling can be collected in the digital environment and presented visually. Modelling historical artefacts' external and internal structures together is a task that can be done with many sessions with classical terrestrial laser scanners. Backpack Lidar Systems are a proper newly applied alternative method in large areas of use and historical buildings where many sessions should be held with terrestrial laser scanner systems. These systems quickly acquire coordinate data and omega, kappa and phi angles differences with internal GNSS/IMU components and save time and cost following photogrammetric mentality. In this research, using Backpack Lidar System; The exterior and interior structure of the village mosque, which is an Ottoman artefact built in 1899 at the Dumanoluğu Village in the Şiran District of Gümüşhane City, was modelled in 3D. With its integrated camera, the point data has been coloured and made suitable for architectural survey studies. The village mosque's exterior scan was completed within seven minutes, and the interior scan within five minutes. 2.041.971 points were obtained in the external scanning, and 821.306 points in the internal scanning. Four GCPs were used for the mosque's exterior screening. The point clouds obtained were combined and modelled. Thus, the model is presently digitally documented.
\end{abstract}

\section{Sırt Lidarının Fotogrametrik Amaçlı Kullanımıyla Kültürel Mirasın Dokümantasyonu}

\author{
Anahtar Kelimeler \\ Dokümantasyon \\ GNSS/IMU \\ Kültürel Miras \\ Sirt Lidarı \\ 3B Model
}

\begin{abstract}
ÖZ
Tarihi eserlerin taşıdığı izleri tespit etmek, gelecek nesillere aktarılmasına vesile olmak, yaşadıkları tahribatları belgelemek için mimari arşivleme çok önemli bir gerekliliktir. Son yıllarda fotogrametrik yöntemlerin gelişimi ile rölöve çalışmalarına yeni bir bakış açısı kazandırılmıştır. 3B modelleme ile elde edilen veri sayısal ortamda saklanabilmekte ve görsel olarak sunulabilmektedir. Tarihi eserlerin dış yapısını ve iç yapısını birlikte modellemek klasik yersel lazer tarayıcılar ile çok sayıda oturumla yapılabilecek bir iştir. Geniş kullanım alanlarında ve yersel lazer tarayıcı sistemleriyle çok sayıda oturum yapılması gereken tarihi yapılarda Sırt Çantası Lidar Sistemleri yeni yeni uygulanan önemli bir alternatif yöntemdir. Bu sistemler koordinat verilerini ve eğiklik, dönüklük, öteleme farklarını dahili GNSS/IMU bileşenleriyle hızlıca elde ederek fotogrametrik anlayışa uygun zamandan ve maliyetten kazanç sağlamaktadırlar. Bu araştırmada, Sırt Çantası Lidar Sistemi kullanılarak; Gümüşhane İli Şiran İlçesi Dumanoluğu Köyü'nde bulunan 1899 yılında yapılan Osmanlı Eseri olan köy camisinin dış ve iç yapısı 3B olarak modellenmiștir. Entegre kamerasıyla nokta verisi renklendirilerek mimari rölöve çalışmalarına uygun hale getirilmiştir. Köy camisinin dış cephe taraması 6 dakika, iç mekân taraması 4 dakika içerisinde tamamlanmıştır. Dış cephe taramasında 2.041.971 nokta, iç mekân taramasında 821.306 nokta elde edilmiştir. Caminin diş cephe taramasında 4 adet YKN kullanılmıștır. Elde edilen nokta bulutları birleștirilmiștir ve modellenmiştir. Sonuç olarak, tarihi cami yapısal olarak sayısal ortamda belgelenmiştir.
\end{abstract}




\section{INTRODUCTION}

Human beings have built important structures for protection, shelter and meeting their basic needs for centuries. These structures have undergone partial or total degeneration due to wars, natural conditions, and people throughout history. Every society has an absolute responsibility to transfer the cultural heritage of humanity to future generations and protect it in the best way. Living in a geography that has hosted the most important civilizations of human histories, such as Anatolian lands, forces a much more important responsibility.

It is a great necessity to use sufficient technological infrastructure and human resources to protect and transfer all cultural artefacts in the borders of our country to future generations. For this purpose, developing and strengthening the use of photogrammetric methods can be seen as a duty. All photogrammetric techniques such as Unmanned Aerial Vehicles (UAV), terrestrial, mobile, and aerial Light Detection and Ranging (lidar) systems, and satellite data can be practised to preserve and document cultural heritage (Kaya et al., 2021; Ulvi et al., 2019; Makineci 2016; Yakar et al., 2014; Yaman \& Kurt, 2019; Bakirman et al., 2020; Elfadaly et al., 2020).

All photogrammetric methods have their own advantages and weaknesses according to the area of use and purpose. According to the literature, it is possible to clarify the success of terrestrial laser scanning systems, which have been widely used in recent years in cultural heritage documentation. Studies have shown that Terrestrial Laser Scanning
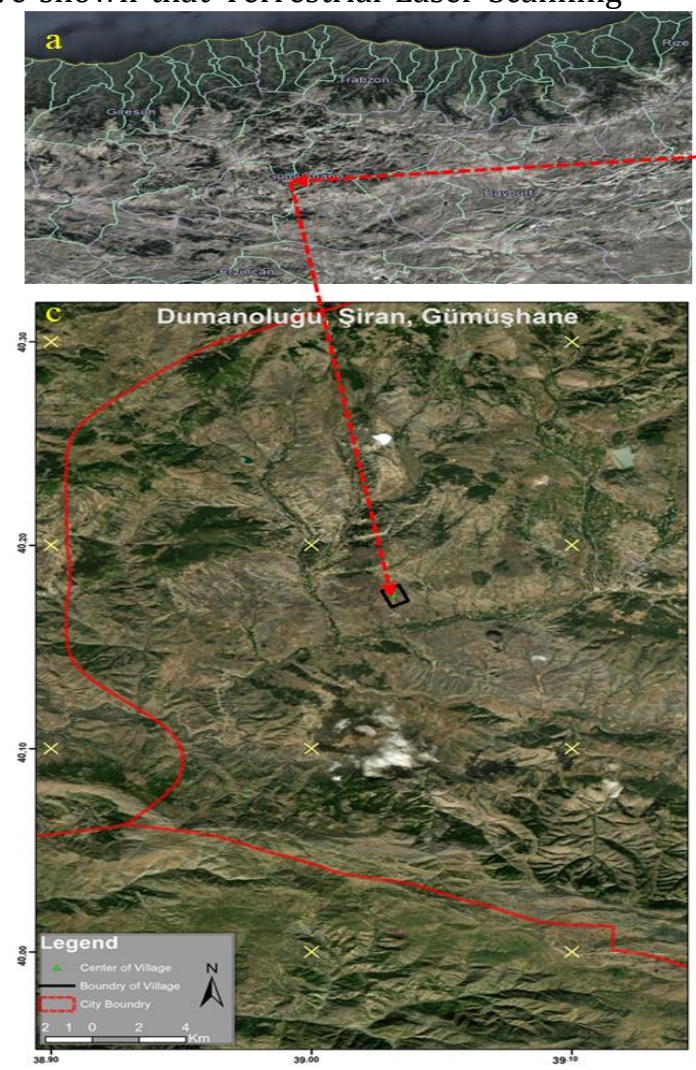

(TLS) systems give better results (Kuçak et al., 2020). However, because of the problems that happen to the loss of time and the increase in the number of sessions (Kör \& Cerit, 2020), researchers need new alternatives (Zeybek, 2019). Backpack Lidar systems, carried by human assistance, are also an inherent alternative solution of recent times. Backpack lidars, which generate colored and kinematic spatial data with integrated camera and Global Navigation Satellite Systems (GNSS) systems and, these systems allow working with angular high precision with the Inertial Measurement Unit (IMU) supported operating systems.

In this study, the positional accuracy and final product (3D Model) success of these systems were tested by documenting a mosque's internal and external architectural features using Backpack Lidar quickly. As a result, it has been determined that these systems offer fast results, innovative and promising.

\section{MATERIALS and METHOD}

\subsection{Study Area}

The historical village mosque belonging to the Dumanoluğu Village of Gümüşhane Province, Şiran District, located in the east of the Black Sea Region, Turkiye, was chosen as the study area. Although it is not clear who built the mosque, it is on the trade line of caravans on the Silk Road as an Ottoman period structure. Its location and interior-exterior structure are shown in fig 1.
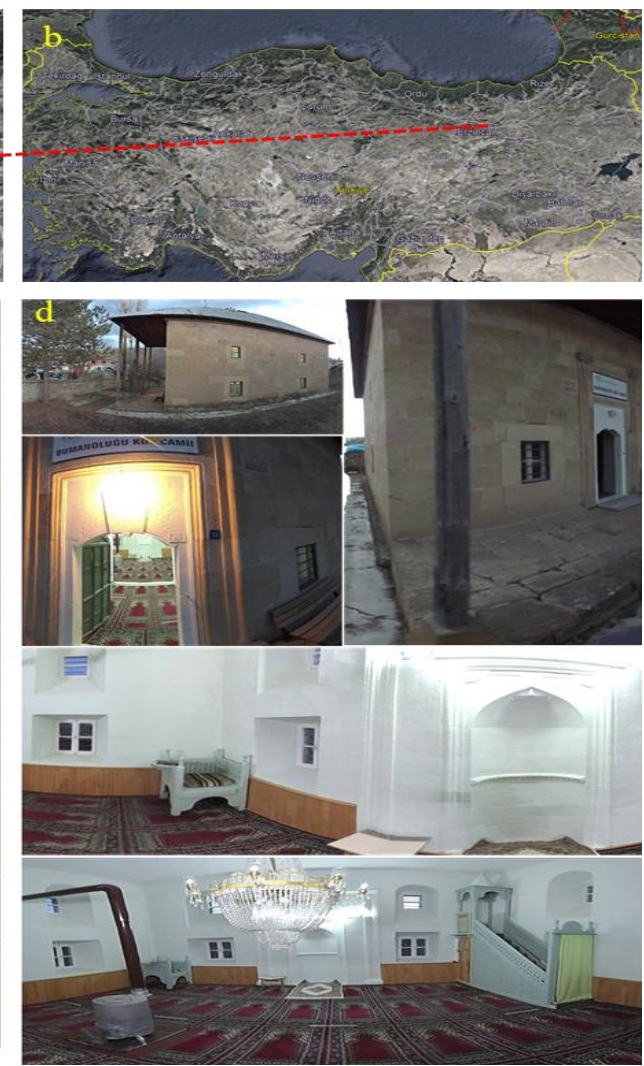

Figure 1. Study area and inside-outside of the mosque (a: Gümüşhane City, b: Position of Gümüşhane City in Black Sea Region, c: Dumanoluğu Village, d: Internal and External Profiles of Mosque) 


\subsection{Backpack Lidar System}

In this study, the Greenvalley Libackpack DGC50 backpack LIDAR system was used. When the backpack LIDAR models are analysed, it is seen that they generally have a single laser sensor and a panoramic camera. Unlike the general, the Libackpack DGC50 model has two laser sensors (one horizontal and one vertical), with a panoramic camera and GNSS/IMU receiver. With the GNSS receiver in the LIDAR system, point data is obtained in coordinates during the sessions held in outdoor dimensions (Fig 2).

The GNSS receiver in the laser scanner works with the PPK method. While providing access to the satellite data required for the PPK, the ground station operating with the static method is used simultaneously. In this way, the horizontal position of the obtained point data can be obtained up to $\pm 7 \mathrm{~cm}$. In addition, the properties of the Lidar used in the study are shown in Table 1 (greenvalleyintl.com 2021).

Table 1. Greenvalley Libackpack DGC50 specs

\begin{tabular}{ll}
\hline Specifications & Value \\
\hline Dimension (mm) & $1010 \times 344 \times 252$ \\
Battery & $5700 \mathrm{mAh}$ \\
Weight & $10.3 \mathrm{~kg}$ \\
Working hours & $\sim 2 \mathrm{~h}$ \\
Laser Sensor & $\mathrm{VLP} 16 \times 2$ \\
Accuracy & $\pm 3 \mathrm{~cm}$ \\
Vertical FoV & $-90^{\circ} \sim 90^{\circ}$ \\
Horizontal FOV & $0^{\circ} \sim 360^{\circ}$ \\
Measuring range & $100 \mathrm{~m}$ \\
\hline
\end{tabular}

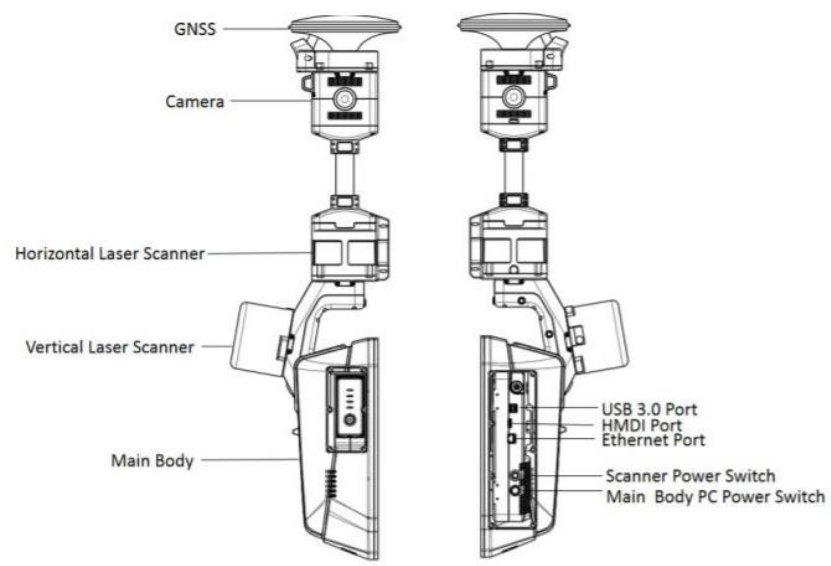

Figure 2. Greenvalley Libackpack DGC50 Profile

\subsection{Workflow of Study}

The general workflow of the study is divided into fieldwork and office work. There are Ground Control Points (GCPs) used in fieldwork and operations for generating lidar data. Office work includes adjustment of GCPs and analysis of point cloud (fig 3).

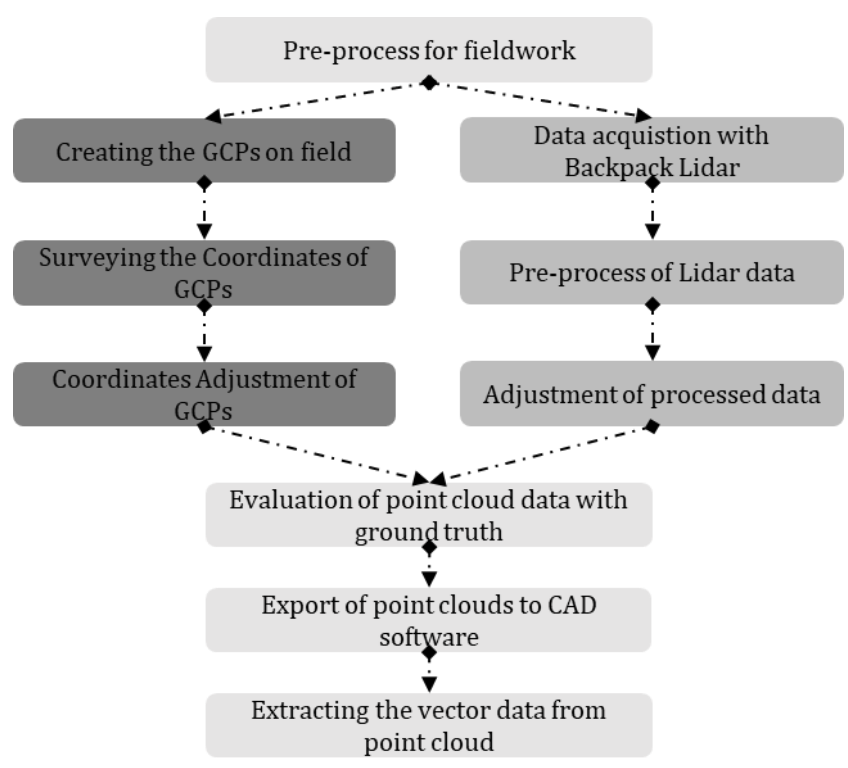

Figure 3. Workflow of fieldwork and office work

\subsubsection{Pre-process for fieldwork}

Determining the Static GNSS receiver location, which is a part of the Lidar system, is considered the first step of the fieldwork planning studies. It is required to determine the location of the fixed GNSS receiver, taking care that there are no high buildings and trees around it. The distance between the static GNSS receiver and the Mobile GNSS receiver in the lidar system should not exceed $3 \mathrm{~km}$.

\subsubsection{Data acquistion}

Lidar system is started around the historical monument to be scanned outdoors. Since the Greenvalley Libackpack DGC50 consists of a laser scanner + panoramic camera + GNSS components, some issues need to be considered before starting data collection. Check that the camera is ready and make sure that the recording process has begun. It is checked that the GNSS receiver is connected to a sufficient number of satellites and that it is ready. It is necessary to wait at least 3 minutes before starting data collection; It is expected to obtain the satellite data required for an accurate coordinating process of the point cloud. After waiting, data is created to be collected after the "8" mark is made slowly on the ground to perform GNSS calibration.

In indoor scanning, it is checked that the camera is ready and the recording process has begun, and then the scanning is started. Since the Mobile GNSS receiver in the Lidar system will be disconnected from the satellite during indoor data acquisition, the GNSS steps performed in the outdoor scan should not be followed.

After the Lidar system is started, the details of the components mentioned above begin to appear on the control unit screen (tablet etc.). The surfaces that the laser scanner touches instantly appear in the control unit by being coloured in dots according to the height values. Also, the scan number of each frame is 
displayed on the control unit. Whether the camera is in recording status, recording time; The number of connected satellites, connection status with satellites, distance travelled, walking speed, working time, IMU data are instantly monitored in the control unit.

Data should be collected, taking into account the laser scanner's beam emission of up to 100 meters. Care should be taken to the quality of the satellite connection so that the GNSS receiver is not disconnected from satellites. Point data obtained from indoor scanning performs coordinate transformation in office work.

While the outdoor scan session is ended; the process steps for the lidar system start-up process are performed oppositely; first, the '8' mark is drawn on the floor, then after waiting at least 3 minutes, the session is terminated after it is concluded that there is no problem by checking the details in the control unit. Simultaneously with the Lidar sessions, ground control points are placed on the floor, and the laser scanner scans the GCPs. Then GCPs are surveyed with a different Cors-GNSS receiver.

\subsubsection{Evaluation of point cloud data with ground truth}

After the fieldwork, camera file, point data file, mobile GNSS data in the lidar system and recording data of the fixed station, an independent part of the system, are obtained. These data are processed in the point data processing software of Lidar company. After uploading the software to convert the data mentioned above into the country coordinate reference system, data parameters are selected. Correction is made to the mobile GNSS data with the data obtained from the fixed station. The process of colouring the point cloud data with the SLAM algorithm with the images obtained in the camera is performed. In this way, the location accuracy of the point cloud data obtained from the laser scanner is \pm 7 $\mathrm{cm}$. As a result, the accuracy of the coordinated and RGB point cloud obtained is provided with the help of GCPs.

\subsubsection{Extracting the vector data from point cloud}

Essential details of the historical artefact are drawn in the point cloud, ready for drawing in the CAD environment. These details can be structures such as doors and windows or historical value objects such as a textured object and an icon. CAD software that supports point cloud formats (.las, .laz, .e57 etc.) is preferred for the drawing process.

\section{RESULTS AND DISCUSSIONS}

In the research, external and internal scanning was carried out to obtain and document the point cloud of the mosque. The external scan of the mosque was completed within 6 minutes (fig 4), and the internal scan within 4 minutes (fig 5). 2.041.971 points were obtained in the external scanning, and
821.306 points were obtained in the internal scanning.

Point data collected with lidar in the study area was transformed into the country coordinate reference system (TUREF / TM39) without any points obtained by terrestrial or photogrammetric methods in the process stage. In the Lidar system, the point cloud data collected by systems without mobile GNSS receivers can be transformed with points obtained by local or photogrammetric methods. The iterative closest point algorithm (ICP), which has been increasingly used in recent years, is preferred for the transformation process. The translation and rotation matrices required for transformation are obtained by using ICP. In order to use the ICP algorithm successfully, at least 3 points are needed (Zeybek, 2019).

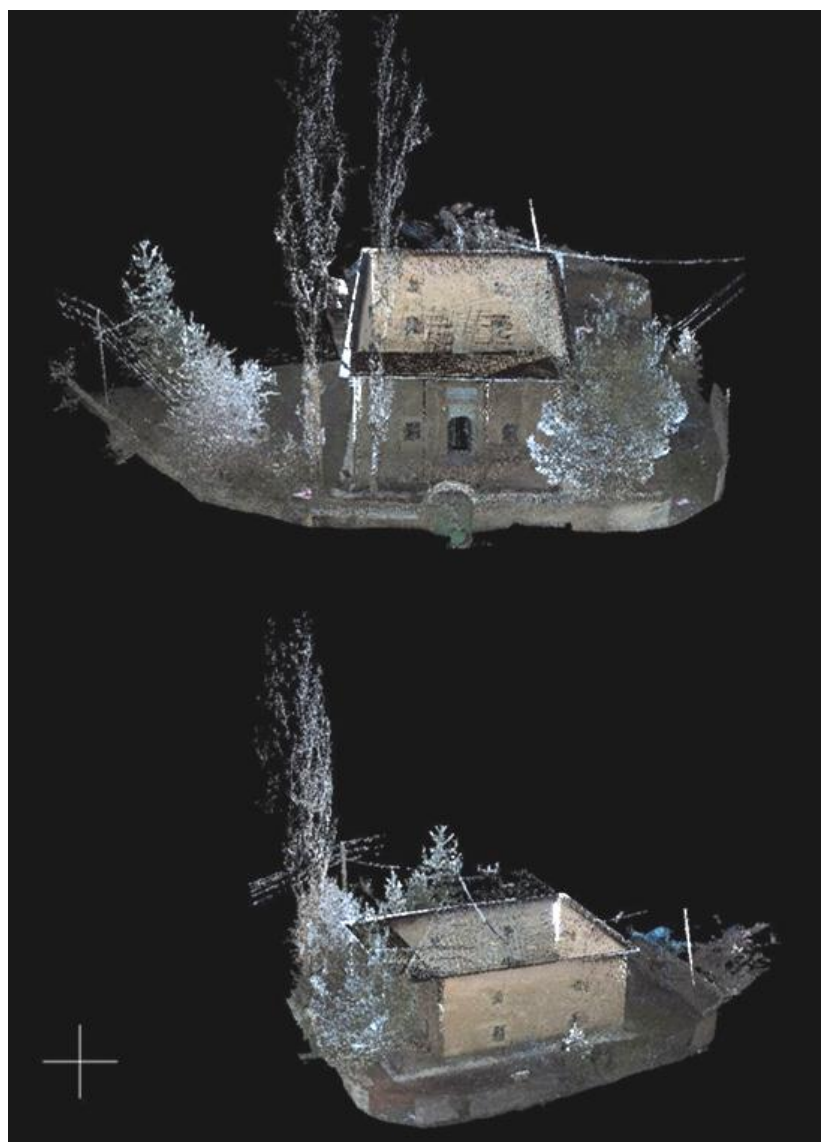

Figure 4. The external scan of the mosque

Today, terrestrial laser scanners are used for historical artefacts, archaeological excavations, etc. It is frequently used in many modelling studies. Terrestrial laser scanners are installed at many points in the area to be scanned, so fieldwork takes a long time. The increase in the number of processes in office work takes a long time due to the efforts to combine the point clouds obtained from different points (Ulvi et al., 2019). When we examine other models of handheld laser scanners, it can be obtained from the laser scanner we use in our work for a long time due to hand-held and single laser scanner fatigue. Less point cloud is obtained from the obtained point cloud (Yaman \& Kurt, 2019). 

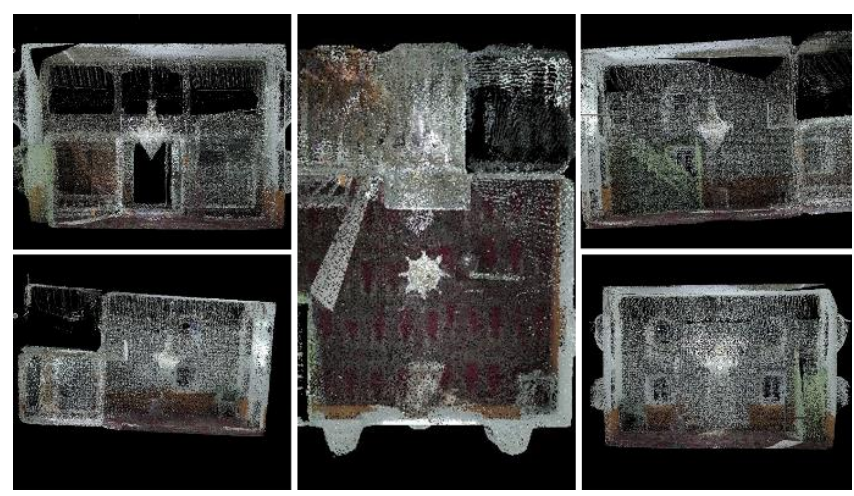

Figure 5. The internal scan of the mosque

Using photogrammetric studies according to the National Large Scale Map Production Regulation (BÖHHBÜY, 2018); It is necessary to use a minimum of 4 checkpoints, up to $30 \%$ of the GCP number. Since the point cloud data collected with the GVI Libackpack DGC50 is coordinated, adjustment is not performed in this study. Considering the minimum number of GCPs, 4 GCPs were measured in the exterior scanning of the historic mosque. Errorvalues of the determined GCPs is given in Table 2 .

Table 2. Minimum, Maximum, Mean Errors of GCPs

\begin{tabular}{lcc}
\hline & Horizontal $(\boldsymbol{X}, \mathbf{Y})(\mathbf{m})$ & Vertical $(\mathrm{Z})(\mathrm{m})$ \\
\hline Min Error & 0.020 & 0.004 \\
Max Error & 0.082 & 0.077 \\
Mean Error & 0.047 & 0.041 \\
\hline
\end{tabular}

As shown in Table 2, successful results have been presented in terms of horizontal and vertical accuracy. The average horizontal error is approximately $5 \mathrm{~cm}$, and the average vertical error is about $4 \mathrm{~cm}$.

The coordinated point cloud is transferred to CAD software. The drawing process (vectorisation of structure) is performed in CAD. In this way, vector data is obtained. The walls of the historical mosque can be obtained in vector form, as in fig 6 .
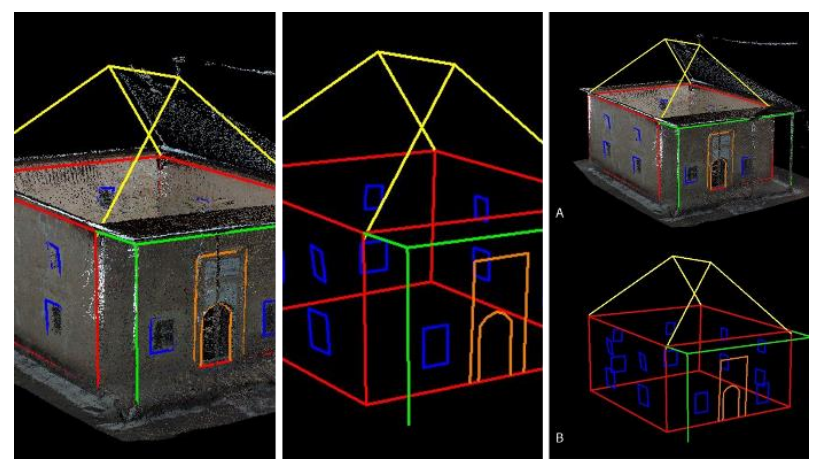

Figure 6. Vectorisation of Structure

\section{CONCLUSION}

This study aimed to determine that the documentation and modelling of historical buildings can be carried out quickly and effectively with Backpack Lidar. The average horizontal error is about $5 \mathrm{~cm}$, and the vertical $4 \mathrm{~cm}$ shows that the study results are adequate. Well-to-do results have been demonstrated with the fieldwork and office work carried out for this purpose.

\section{ACKNOWLEDGEMENT}

The authors declare their appreciation to Küre Engineering, which made an essential contribution to obtaining the data.

This study was presented as an oral presentation in the "The 2nd Intercontinental Geoinformation Days (IGD) 2021.

\section{REFERENCES}

Bakirman T, Bayram B, Akpinar B, Karabulut M F, Bayrak O C, Yigitoglu A \& Seker D Z (2020). Implementation of ultra-light UAV systems for cultural heritage documentation. Journal of Cultural Heritage, 44, 174-184.

Elfadaly A \& Lasaponara R (2020). Cultural heritage management using remote sensing data and GIS techniques around the archaeological area of ancient Jeddah in Jeddah City, Saudi Arabia. Sustainability, 12(1), 240.

Kaya Y, Yiğit A Y, Ulvi A \& Yakar M (2021). Arkeolojik Alanların Dokümantasyonununda Fotogrametrik Tekniklerinin Doğruluklarının Karşılaştırmalı Analizi: Konya Yunuslar Örneği. Harita Dergisi, 165, 57-72.

Kör M \& Cerit A (2020). Konya Teknik Üniversitesi Sürekli Eğitim Uygulama ve Araştırma Merkezi Rölöve Projesinin Lazer Tarama Yöntemiyle Hazırlanması. Turkey Lidar Journal, 2 (1), 10-14. Retrieved from https://dergipark.org.tr/tr/pub/melid/issue/55 648/729956

Kuçak R, Erol S \& İşiler M (2020). Comparative Accuracy Analysis of Lidar Systems. Turkey Lidar Journal, 2 (2), 34-40. Retrieved from https://dergipark.org.tr/tr/pub/melid/issue/58 409/827438

Makineci H B (2016). İnsansız Hava Araçları Lidar Etkileşimi. Geomatik, 1(1), 19-23.

Ulvi A, Varol F \& Yiğit A Y (2019). 3D modeling of cultural heritage: the example of Muyi Mubarek Mosque in Uzbekistan (Hz. Osman's Mushafi). International Congress on Cultural Heritage and Tourism (ICCHT), 115-123, Bishkek, Kyrgzstan.

Yakar M, Yılmaz H M \& Mutluoglu O (2014). Performance of photogrammetric and terrestrial laser scanning methods in volume computing of excavation and filling areas. Arabian Journal for 
Science and Engineering, 39, 387-394. https://doi.org/10.1007/s13369-013-0853-1

Yaman A \& Kurt M (2019). Tarihi ve kültürel mirasların belgelenmesi ve üç boyutlu modellenmesi için Geoslam yersel lazer tarayıcının kullanım olanaklarının araştırılması: Aksaray İli Ulucami Örneği. Türkiye Lidar Dergisi, 1(1), 5-9.

Zeybek M (2019). El-tipi LiDAR ölçme sistemleri ve 3B veri işleme. Türkiye Lidar Dergisi, 1(1), 10-15.

\section{BÖHHBÜY.}

Retrieved

from: https://www.mevzuat.gov.tr/MevzuatMetin/3.5. 201811962.pdf

https://greenvalleyintl.com/wpcontent/uploads/2020/10/LiBackpackDGC50.pd $\mathrm{f}$

(C) Author(s) 2021. This work is distributed under https://creativecommons.org/licenses/by-sa/4.0/ 